\title{
Precaution and Innovation in the Context of Wastewater Regulation: An Examination of Financial Innovation under UWWTD Disputes in London and Milan
}

\author{
Fritz-Julius Grafe ${ }^{1, *(\mathbb{D})}$ and Harald A. Mieg ${ }^{2}$ \\ 1 Department of Geography, University of Zurich, 8057 Zurich, Switzerland \\ 2 Institute of Geography, Humboldt-Universität zu Berlin, 10099 Berlin, Germany; harald.mieg@hu-berlin.de \\ * Correspondence: fritz-julius.grafe@geo.uzh.ch
}

check for

updates

Citation: Grafe, F.-J.; Mieg, H.A. Precaution and Innovation in the Context of Wastewater Regulation: An Examination of Financial Innovation under UWWTD Disputes in London and Milan. Sustainability 2021, 13, 9130. https://doi.org/ $10.3390 /$ su13169130

Academic Editor:

Haywantee Ramkissoon

Received: 6 July 2021

Accepted: 5 August 2021

Published: 15 August 2021

Publisher's Note: MDPI stays neutral with regard to jurisdictional claims in published maps and institutional affiliations.

Copyright: (c) 2021 by the authors. Licensee MDPI, Basel, Switzerland. This article is an open access article distributed under the terms and conditions of the Creative Commons Attribution (CC BY) license (https:// creativecommons.org/licenses/by/ $4.0 /)$.

\begin{abstract}
The Water Framework Directive (WFD) under the guidance of the precautionary principle sets out standards to guarantee high quality water services for European citizens. This creates pressure on European cities to update and renew their water infrastructures in accordance with EU Law at great financial cost. Cities within the Union try to bridge this financial gap with a variety of approaches. This paper presents the cases of London and Milan, both of which were subject to legal proceedings for breaching the Urban Waste Water Treatment Directive. By example of these two cases, this article details how the precautionary principle affects urban water infrastructure provision, and how the regulation of the primary risk of pollution can both trigger innovation and create secondary risks within the highly integrated urban water infrastructure sector. The London case focusses on an individual infrastructure project and shows how its financial framing has compromised the final outcome, while the Milan case presents a longer-view perspective that shows how structural changes in the urban water infrastructure sector have enabled an environment for sustainable financial innovation. The role of transparency and good local governance practices are emphasized for a successful implementation of the precautionary principle requirements in a city's water sector. Managing this process effectively can result in meaningful social innovation for urban water infrastructure provision.
\end{abstract}

Keywords: innovation; infrastructure; financializaton; precautionary principle

\section{Introduction}

Many European cities are facing the challenges of having to massively overhaul their urban water infrastructures. Ageing and overburdened systems first installed in the 19th century are challenged by increasing environmental standards imposed by European regulation. Water legislation in the European Union is defined by the Water Framework Directive (WFD) and its various daughter directives. These directives form the legal frame for European, national and regional policies for water protection. The Marine Strategy Framework Directive, the Nitrates Directive and the Floods Directive further support these. Furthermore, the 'Water Industry Directives' (Urban Waste Water Treatment, Drinking Water Directive, and the Bathing Water Directive) provide complementary legislative tools for the safe management of sewage, the protection of drinking and bathing waters. These pieces of legislation form the core of water policy in the European Union and each address separate issues within the water sector. As these issues are still closely interrelated, these directives mutually impact compliance [1] (p. 5). The Urban Waste Water Treatment Directive (UWWTD) is of particular note for the purposes of this paper, as it has been utilized to legally challenge cities within the European Union that do not comply with the required standards.

These standards are closely tied to the precautionary principle. The precautionary principle is one of the core principles of the WFD and is established in article 11. The precau- 
tionary principle is "a guiding principle that allows decision-makers to adopt precautionary measures even when scientific uncertainties about environmental and health impacts of new technologies or products remain" [2]. The precautionary principle itself is subject to ongoing debates: there are numerous voices that claim that the precautionary principle hinders innovation and only triggers new risks due to uncertain side effects [3]. While, it is also known from research that carefully selected environmental regulations can lead to innovation [4]. There is a discrepancy in how the precautionary principle is being put to use: there is an emphasis on making use of the principle by applying it to the factors that trigger its application, there is less guidance on how to implement precautionary measures that prevent this triggering in the first place [2]. Thus, the precautionary principle by means of the WFD enacts immense influence over the way we organize and manage our cities' water systems: it triggers punitive measures in case key factors are not met, but it does not prescribe precautionary measures that would help cities maintain good standing with those factors. There is a certain consensus that the implementation of the precautionary principle can preferably be done by means of Responsible Research and Innovation (RRI). RRI is a conceptual framework for integrative research policy, primarily at the EU level [5]. From the EU side, the principle of democratic governance is emphasized above all, namely that "societal actors work together during the whole research and innovation process in order to better align both the process and its outcomes with the values, needs, and expectations of European society." [6]. Authors of RRI (e.g., [7]) at the same time emphasize aspects of responsiveness, for example, anticipation as the ability to consider alternatives and to ensure reversibility.

The ensuing situation presents cities with an enormous task: in order to avoid these legal challenges, cities have to invest immense sums beyond their financial capacity into their water infrastructure. This 'infrastructure gap' engages a variety of actors that develop different strategies for bridging it. Arguably, this raising of environmental standards under the precautionary principle might foster a particular kind of innovative milieu that strives to overcome the infrastructural challenges at hand [4]. A key area here is the question of finance and the emergence of new financial arrangements to bridge the gap. Within the literature this process is most commonly discussed in the context of the financialization of urban infrastructure, with a variety of long-term implications for urban development, politics and policy (see for example [8-11]).

Two cities that were subject to legal proceedings under the UWWTD are London in the United Kingdom and Milan in Italy. By example of these two cases, this article will detail how the precautionary principle affects urban water infrastructure provision, and how the regulation of the primary risk of pollution can both trigger innovation and create secondary risks within the highly integrated urban water infrastructure sector. This balancing of risks and innovation in a multi-risk environment is one of the key challenges for the precautionary principle in the infrastructure sector, where the regulation of one aspect might lead to the introduction of regrettable substitutions elsewhere; this is particularly significant in an environment in which the way we finance water infrastructure development is fundamentally changing (see for example [12,13]). The overall challenges of integrating water services more closely with long-term urban planning objectives has been recognized as one of the key issues for improving European water policy [1]. Koop and Leeuwen emphasize this point and helpfully provide a comprehensive perspective on the resulting needs for good water governance [14] (see Table 1). This contribution investigates by example of these two cases whether the precautionary principle by means of the UWWTD instigated social innovation in the water infrastructure development process and if so, which particular innovations we can identify. 
Table 1. Good water governance. Adapted from Koop and van Leeuwen 2017 [14].

\section{Good Water Governance}

1. Develop a shared long-term vision between stakeholders.

2. Involve civil society and the commercial sector, along with stakeholders: recognizing that citizens and private businesses can individually contribute to success.

3. Manage the process and expertise: to address the complexity of the challenge, conflicting interests, and the need to remain focused on a long-term vision.

4. Stop excessive focus on technology development: recognizing that good governance is equally essential for success.

5. Make data accessible and share knowledge.

6. Carry out a thorough cost-benefit analysis and remove financial barriers: success is not dependent on simply providing more money. Limited finance can drive innovation, improve stakeholder cooperation, and help leverage new funding sources.

7. Monitor implementation: legislation and a good strategy must be supported by a demonstration that implementation and achievements progress as intended

\section{Methods}

This article is based on two case studies that were conducted for the RECIPES project (recipes-project.eu). The data is based on 15 interviews (can be found in Supplementary Material) with experts and practitioners in the fields of finance and water infrastructure provision, as well as on a document analysis of 224 documents issued by relevant institutions related to the two sites (see Table 2). The cases were selected for their similarities with regard to the legal issues surrounding the failure to comply with the UWWTD and their very different approaches for implementing the verdicts. The following presents an overview over key aspects of the two cases (also see Figure 1).

Table 2. Document analysis data.

\begin{tabular}{cc}
\hline Source & Number of Documents \\
\hline Documents by Responsible Ministries & 18 \\
Documents from Environmental Agencies & 15 \\
Documents from the European Commission & 27 \\
Documents from Local Administrations & 25 \\
Reports issued by Local Water Service Companies & 43 \\
Reports from Regulators and Oversight Institutions & 37 \\
Reports from Investors & 10 \\
Documents from Political Organizations & 9 \\
Expert Reports & 16 \\
Press Reports & 24 \\
\hline
\end{tabular}




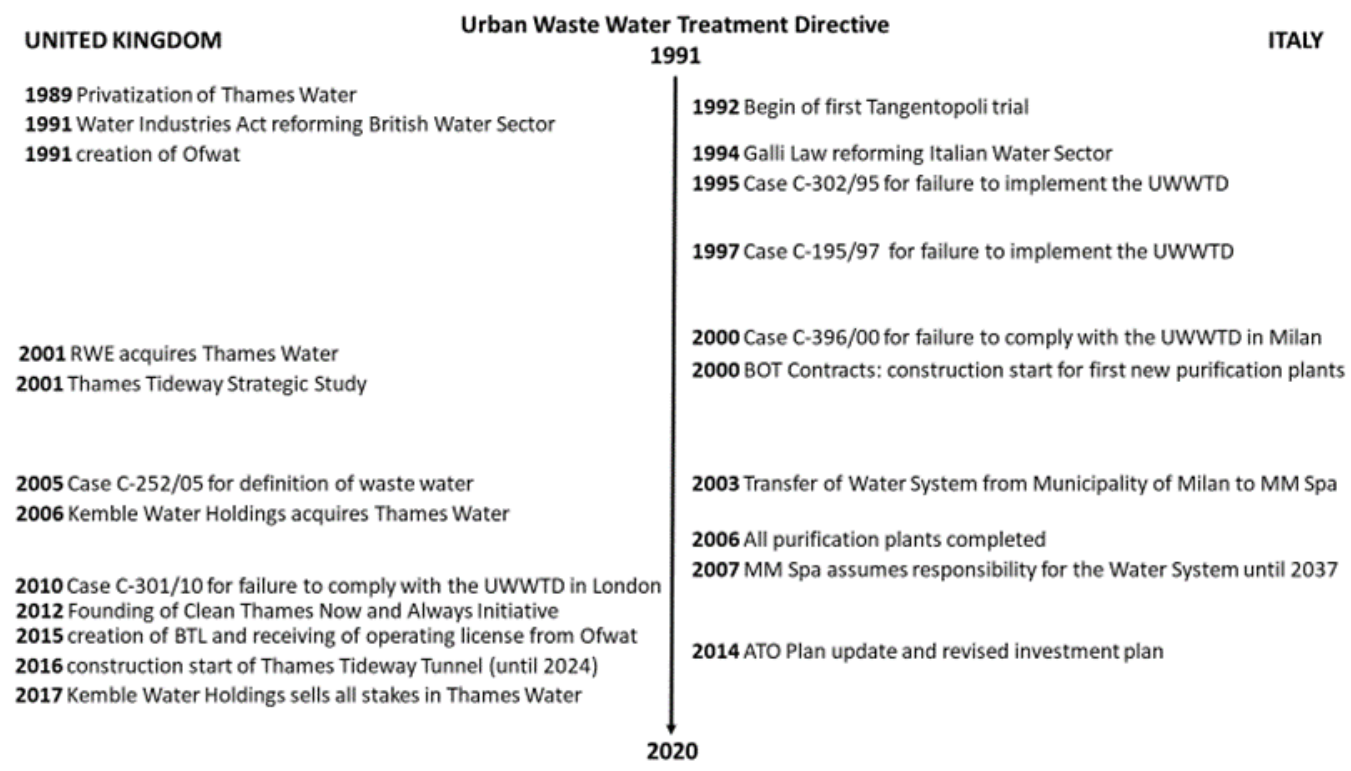

Figure 1. Timeline of the cases.

\subsection{London}

The 2010 legal case against the United Kingdom centered around the overflow of the sewage system into the river Thames in case of minimal rainfall $[15,16]$. The case argues that under the UWWTD London does not provide adequate infrastructure for the prevention of pollution. As a consequence, the city was presented with the challenge to fix the problem and present a solution that was both capable of coping with the difficult postfinancial crisis funding situation as well as the long-term infrastructural challenges present in London. A strategic study was implemented by the Environmental Agency, Thames Water (TW), Department for Environment, Food and Rural Affairs (DEFRA, the responsible ministry) and the Greater London Authority to determine appropriate solutions [17]. Funding allocation for the different involved sciences was questioned later on, as the results were biased towards large-scale engineering solutions [18]. The selected solution was the adaptation of the water system to and the construction of a $25 \mathrm{~km}$ tunnel under the River Thames that effectively acts as a secondary sewer system that catches the overflow of the first when it becomes overburdened. Construction is ongoing and the cost is estimated at GBP 4.2 billion total. Controversies around the project relate to a lack of transparency in selection process following the strategic study, a weak tender process, a questionable financial model as well as challenges to the entire raison d'être of the project, since its services are projected to be no longer necessary (see $[8,19]$ ).

\subsection{Milan}

The legal case brought against Italy in 2000 for Milan's ongoing dumping of untreated waste water into the river system, handles a similar issue, however it is larger in scale. The legal case results from previous cases against Italy for the failure to implement the UWWTD into national law and points out the immense structural changes that had to be implemented in cities across Italy (see [20-22]). Milan was at the time the last major European city still dumping untreated waste water. Due to these proceedings, Milan has been the subject to an infringement procedure by the EU Commission. A reason for the EU Commission's hesitance to impose a pecuniary sanction was most likely due to the belated awarding of construction contracts to private consortia. Milan had to construct two completely new purification plants and implement major upgrades in a third between 1999 and 2006. The awarded BOT (Build-Operate-Transfer) contracts were surrounded by controversy over bribery, lack of transparency and restricted competition. These events 
were still very much in line with ongoing fallout from the 1990s Tangentopoli phenomena ("Bribesville", referring to corruption in public works contracts). These scandals facilitated structural changes in the operation of Milan's water sector, particularly with the transfer of the management responsibility for the integrated water system from the Municipality to MM Spa, a multiservice company fully owned by the Municipality of Milan. Even though the way these structural changes were implemented are still not free of criticism and path dependencies resulting from the BOT contracts are still strong, today, Milan's water system has emerged from this transformation process with several technological and financial innovations, that set it apart from fixes such as those that were applied in London.

\section{Results}

In the following we will examine the cases in more detail and explore how their different dynamics relate to processes of financial, institutional and to a lesser extent technical innovation.

\subsection{London: Financial Innovation in the Dark}

To understand the financial innovation within the London case, we have to shine a light on the Thames Water's (TW) trajectory and practices in recent years. Thames Water is the key actor for the Tideway Tunnel project, they supply about 9 million customers with water and are responsible for the wastewater of about 15 million customers within South-East England [23]. TW was first privatized in 1989 and has since undergone several takeovers and restructurings. This has resulted in lower credit ratings which mostly result from overleveraging of the underlying assets to finance these takeovers [15]. TW was first listed on the London Stock Exchange but has since been unlisted and employed an increasingly byzantine off-shore structure, which in 2012 consisted of 10 corporate layers between shareholders and the licensed water company. For example, the off-shore subsidiary Thames Water Cayman Island Finance Ltd. holds over half of Thames Water's GBP 10 bn long-term debt. The ultimate owner of TW is the consortium of international investment funds Kemble Holdings Limited, who mostly refinance their investment debts by securitizing household revenue streams [24].

TW financially weak position has resulted in the fact that project delivery is being implemented by a separate entity, Bazalgette Tunnel Limited (BTL), a new special-purpose company with an off-shore holding structure similar to that of TW. The financing scheme passes a proportion of the project costs on to Thames Water's costumer bills, with an estimated GBP 25 added per annum in the mid-2020s. Martin Blaiklock, an independent infrastructure finance expert states that this scheme where customers pay both during the construction phase as well as during service delivery is contrary to common investment principles, as it transfers the project completion risk from utility company to the customer [18]. He concludes that "the incentive for contractors to achieve project completion to time and cost is now much diminished, if not eliminated. Furthermore, customers cannot manage, control or mitigate such risks" (id., p. 4).

Both TW as well as BTL are regulated by Ofwat (Office of Water Services), whose main responsibility lies in the negotiation of tariffs every 5 years based on Thames Water's business plans and Ofwat's internal Regulatory Assets Base Model (RAB). The relatively weak negotiating position of the regulator has been acknowledged and has been the subject of recent politics within the United Kingdom's political process.

The documented increasing withdrawal from oversight mechanisms as well as the relatively weak position of oversight authorities has provided an environment in which financial innovation occurs 'in the dark', and at the cost of future risks [8]. The mechanism succeeds in providing the necessary financial capital but obfuscates key categories that are necessary for cities to manage their planning risks. 


\subsection{Milan: Institutional Innovation and a Way Out}

The history of corruption, lack of transparency, legal proceedings as well as costly BOT contracts have provided for a tough heritage for MM Spa to sort through. MM Spa itself is a joint-stock company $100 \%$ owned by the Municipality of Milan. Originally primarily an engineering company and formed in 1955 for the construction of Milan's metro system, it today covers both mobility and infrastructure engineering as well as management duties for municipal housing and other public assets. Outside these core activities MM Spa also engaged in international investments with a joint venture in Moscow with Millenium Bank, part of the Russian Railways group, which shortly thereafter went bankrupt and lost its banking license [25].

The territory and duties for operations of MM Spa is defined by the restructuring of water supply and sanitation operations in Italy through the 1994 Galli Law. According to it, responsibility for water supply and sanitation is transferred to a public authority called ATO (Ambito Territoriale Ottimale). The ATO's governing body selects the water operator and determines the organizational form for water operations. It further carries the responsibility for surveying infrastructure, developing the investment program, setting tariffs and regulating the water operator. This is done via the technical secretariat within the administrative structure of the municipality of Milan.

This sets the framework within which actors aim to provide adequate solutions despite historical baggage and pressing future challenges. Following the 2014/2015 updates to the ATO plan, MM Spa was presented with the challenge of developing an investment strategy to match the plan's requirements to maintain the current level of service as well as adapt the system to future technical and environmental challenges [26].

The key innovative moment is the bilateral development of principles for the financial strategy design and execution between MM Spa and the municipality. This is done to balance the systems long-term requirements with financial viability and current economic opportunities. Stefano Cetti, the director general of MM Spa, summarizes these as follows: "first, total IWS financial needs coverage; second, source diversification; third, risk and collateral minimization; fourth, increase in debt maturity" [27].

The first aspect refers to the principle that the total financial needs of the system up until 2037 (the end of the concession of the system to MM Spa) have to be covered, while guaranteeing coherence between old and newly employed tools, acknowledging current obligations and avoiding the insurgence of refinancing risks [27]. Source diversification refers to the fact that MM Spa aims to take advantage of favorable market conditions and be able to employ different financial instruments outside of traditional bank loans that line up with tariff and investment projections. In order to be able to do this MM Spa acquired credit ratings at the corporate level from Moody's and Standard and Poor's. As a result of this diversification, risks are spread more widely. Risk and collaterals minimization further refers to the fact that the overarching aim is self-sufficiency, thus it aims to minimize risks both to MM Spa as well as the municipality of Milan resulting from instruments that require specific collaterals. The final aspect focusses on the employ of instruments that match in duration the lifetime of the underlying assets. This effectively greatly extends the debt duration, thus heavily emphasizing long-term instruments with a duration of up to 20 years (id.).

These principles were successfully put to practice with the employment of two financial instruments: first, by issuing institutional amortizing notes for an amount EUR $100 \mathrm{mln}$, to be listed on the regulated Main Securities Market of the Irish Stock Exchange; second, the negotiation with the European Investment Bank (EIB) for a credit facility of EUR 70 million. Both of these instruments are innovative on several levels in reference to Italian water sector practices [27].

\subsection{Innovation, Precaution and Shining a Light}

The London case focusses on an individual infrastructure project and shows how financial innovation has shaped the case. The Milan case presents a longer-view perspective 
that shows how structural changes in the infrastructure sector have enabled an environment for institutional innovation that gave rise to sustainable financial innovation. With regard to technological innovation for infrastructural solutions, the Tideway Tunnel project is filled with such innovations that make the construction of a tunnel under a river across the breadth of city possible. The project itself greatly stimulated the logistics, construction and engineering sectors across the city. Similar patterns occurred in Milan, where individual technical solutions won awards for their innovative approaches [28].

However, the cases provide two different perspectives on financial innovation in the field. The London case focusses on a specific project that employs a highly individualized financial strategy to the benefit of investors, whereas the Milan case presents a perspective that is more focused on the city's long-term needs. Both of these had to employ financial as well as institutional innovation to develop a viable model for the cities' infrastructure development. However, how we pay for infrastructure influences what is to be built, how it is going to be done and the location where it will happen. Thus, a novel financial model introduces new variables into a city's water system, potentially introducing new risks and vulnerabilities.

The innovative impetus induced by the regulatory framework triggered a cascade of innovation in the water sectors of both cities. A critique could be made of the fact that these innovations are unintended and thus unguided, often resulting in the shifting of risks from one area to the next. The vacuum of the infrastructural gap has provided an arena in which, as illustrated in the London case, financial innovation can take advantage of obfuscation strategies and profit of off an imbalance of knowledge between actors. However, the Milan case shows how even despite a difficult starting proposition, financial and institutional innovation can occur in a sustainable and impactful manner. Here in particular, potential exists to translate this occurrence of an institutional innovation into a social innovation that emphasizes transparency and the co-creation of financial strategy development for urban infrastructure provision.

Furthermore, if we understand the implementation of precautionary principle in terms of RRI, as introduced earlier, the solution found in Milan seems to be more in line with the precautionary principle than the one found in London. With respect to the criterion of democratic governance, the stakeholder-oriented, public structure of MM Spa is preferable to the non-transparent financing construct of the Tideway Tunnel. Additionally, with respect to the responsiveness criterion, the "rolling" development and funding solution in Milan seems more advantageous than the ring-fenced technology-led solution in London.

\section{Discussion}

London's individual infrastructure case shows how the implementation of a marketbased strategy skews the selection of actors and the resulting decision-making process towards an overly economically focused solution, that fails to address some of the longterm planning and financial risks. The viability of this strategy will only become known with time, the Milan case though provides some evidence towards the risks inherent in this strategy. Milan presents the longer-term perspective and the effects of past decisions in terms of path dependencies for the adaptation of the water system to future challenges. The process that was developed was informed by the complicated history of the case and innovative in the regard that it developed a process that involved a more balanced set of opinions and outlooks during the decision-making process than the previous case.

The application of the precautionary principle through the UWWTD has significant impact on urban development, particularly due to its skewed emphasis on triggering punitive measures without providing help for implementing precautionary measures (see [2]). Its application creates space for innovation with both potential for sustainable social innovation as well as unintended shifting of risks from environmental impacts towards long-term planning risks and economic vulnerability of cities. The examination of the cases further shows how the complexity of the water sector challenges good governance practices and how external pressures such as those instigated by the directives can lead to 
potentially undesirable reconfigurations. It is thus evident that the role of transparency and good local governance practices are essential for a successful implementation of precautionary measures in a city's water sector.

These findings speak directly to Koop and Van Leeuwen's key elements for good water governance ([14], see Table 1). Particularly the first element's emphasis on a shared long-term perspective (1) becomes evident and is further supported by the need for the involvement of all affected actors (2) and the acknowledgement of the complexity and long-term effects (3). As the Milan case has shown, better long-term solutions become viable when these measures are adhered to (4). In particular, the crucial role of financial innovation has been well documented in the cases (5).

As we have shown, it is not always possible to adhere to these principles, especially in a scenario where legal requirements push for immediate action on projects with significant long-term impacts. This often leads to more reactive and ad-hoc implementation of infrastructural solutions. This dynamic paired with the vested interests of certain actor groups in the water sector increases the risk of the creation of 'white elephants', that is expensive infrastructure assets that are more trouble in the long-run than they are worth in the short-term. The case of London provides a telling example of this dynamic. The case of Milan on the other hand shows how past experience and a pro-active use of the innovation aspect of the precautionary principle can foster an environment that achieves good local governance practices and transparent processes that not only help to avoid the creation of further white elephants, but facilitate the creation of a sustainable social innovation in the guise of the co-creation of financial strategy development between utility and city.

Triggering and applying the precautionary principle requires a series of science-based risk assessments [2]. How these should be commissioned and interpreted is politically and legally underdetermined. In this respect, reference can really only be made to the more developed policy advice of risk and technology impact research. Stakeholder inclusion, modeling anticipation and systemic consideration of reversibility have become standards in this field $[29,30]$.

What remains is that the precautionary principle's impact on European cities by means of the WFD and its daughter directives is immense: while triggering the principle is relatively easy for cities, implementing the precautionary measures necessary for fulfilling its obligations is not (see [2]). The repercussions of these impacts are not yet fully explored, especially when it comes to the aspect of innovation. We here have provided some evidence towards the instigation of a social innovation in the financial frameworks of water infrastructure development in the case of Milan.

Supplementary Materials: The following are available online at https:/ /www.mdpi.com/article/10 $.3390 /$ su13169130/s1, Table S1: Documents and interviews.

Author Contributions: Conceptualization, F.-J.G. and H.A.M.; methodology, F.-J.G. and H.A.M.; investigation, F.-J.G.; writing—original draft preparation, F.-J.G.; writing—review and editing, H.A.M.; visualization, F.-J.G.; supervision, H.A.M.; project administration, H.A.M.; funding acquisition, H.A.M. Both authors have read and agreed to the published version of the manuscript.

Funding: The RECIPES project has received funding from the European Union's Horizon 2020 research and innovation programme under grant agreement No. 824665.

Informed Consent Statement: Informed consent was obtained from all subjects involved in the study.

Conflicts of Interest: The authors declare no conflict of interest. The funders had no role in the design of the study; in the collection, analyses, or interpretation of data; in the writing of the manuscript, or in the decision to publish the results. 


\section{References}

1. EurEau. WFD-the Need for Greater EU Policy Coordination. EurEau Position Papers140, 1-23. 2017. Available online: http://www.eureau.org/resources/position-papers/140-greater-eu-policy-coordination-may2017/file (accessed on 14 July 2021).

2. De Smedt, K.; Vos, E. The application of the precautionary principle in the EU. In The Responsibility of Science; Mieg, H.A., Ed.; Springer: Cham, Switzerland.

3. Sunstein, C. Laws of Fear: Beyond the Precautionary Principle; Cambridge University Press: Cambridge, UK, 2009.

4. OECD. Effects of the VOC Incentive Tax on Innovation in Switzerland: Case Studies in the Printing, Paintmaking and Metal Cutting Industries; Schoenenberger, A., Mack, A., Eds.; Environment Directorate, Centre for Tax Policy and Administration: Paris, France, 2009.

5. $\quad$ von Schomberg, R. A Vision of Responsible Research and Innovation. In Responsible Innovation: Managing the Responsible Emergence of Science and Innovation in Society; Owen, R., Bessant, J., Heintz, M., Eds.; Wiley: Hoboken, NJ, USA, 2013; pp. 51-74.

6. European Commission. Responsible Research and Innovation: Europe's Ability to Respond to Societal Challenges. 2012. Available online: https:/ / ec.europa.eu/research/swafs/pdf/pub_rri/KI0214595ENC.pdf (accessed on 12 May 2021).

7. Owen, R.; Macnaghten, P.; Stilgoe, J. Responsible Research and Innovation: From Science in Society to Science for Society, with Society. Sci. Public Policy 2012, 39, 751-760. [CrossRef]

8. Grafe, F.-J. Finance, water infrastructure, and the city: Comparing impacts of financialization in London and Mumbai. Reg. Stud. Reg. Sci. 2020, 7, 214-231. [CrossRef]

9. Pike, A.; O'Brien, P.; Strickland, T.; Tomaney, J. Financialising City Statecraft and Infrastructure; Edward Elgar Publishing: Cheltenham, UK, 2019.

10. O'Brien, P.; Pike, A. The governance of local infrastructure funding and financing. Infrastruct. Complex. 2015, 2, 3. [CrossRef]

11. Ashton, P.; Doussard, M.; Weber, R. Reconstituting the state: City powers and exposures in Chicago's infrastructure leases. Urban Stud. 2014, 53, 1384-1400. [CrossRef]

12. Loftus, A.; March, H.; Purcell, T.F. The political economy of water infrastructure: An introduction to financialization. Wiley Interdiscip. Rev. Water 2018, 6, e1326. [CrossRef]

13. Grafe, F.-J.; Mieg, H.A. Connecting financialization and urbanization: The changing financial ecology of urban infrastructure in the UK. Reg. Stud. Reg. Sci. 2019, 6, 496-511. [CrossRef]

14. Koop, S.H.A.; Van Leeuwen, C.J. The challenges of water, waste and climate change in cities. Environ. Dev. Sustain. 2017, 19, 385-418. [CrossRef]

15. CJEU, Court of Justice of the European Union. Judgement ECLI:EU:C:2007:276, CASE C-252/05. 2007. Available online: https:/ / curia.europa.eu/juris/liste.jsf?language=en\&num=C-252/05 (accessed on 14 August 2021).

16. CJEU, Court of Justice of the European Union. Judgement ECLI:EU:C:2012:633, CASE C 301/10. 2012. Available online: https:/ / curia.europa.eu/juris/liste.jsf?language=EN\&num=C-301/10 (accessed on 14 August 2021).

17. Thames Tideway Strategic Study. In Thames Tideway Strategic Study Steering Group Report; Mayor of London, Ofwat, Environment Agency, Thames Water: London, UK, 2005.

18. Blaiklock, T.M. Thames Water, the Thames Tideway Tunnel: Regulatory Weaknesses lack of Transparency: A Flawed Project Structure and Conflicts of Interest, private document provided by the author. 2017.

19. Grafe, F.-J.; Hilbrandt, H. The temporalities of financialization: Infrastructures, dominations, and openings in the Thames Tideway Tunnel. City 2019, 23, 606-618. [CrossRef]

20. CJEU, Court of Justice of the European Union. Judgement ECLI:EU:C:1996:502, CASE C-302/95. 1996. Available online: https:/ / eur-lex.europa.eu/legal-content/EN/TXT/?uri=CELEX\%3A61995CJ0302 (accessed on 14 August 2021).

21. CJEU, Court of Justice of the European Union. Judgement ECLI:EU:C:1999:100, CASE C-195/97. 1999. Available online: https:/ / eur-lex.europa.eu/legal-content/EN/TXT/?uri=CELEX\%3A61997CJ0195 (accessed on 14 August 2021).

22. CJEU, Court of Justice of the European Union. Judgement ECLI:EU:C:2002:261, CASE C-396/00. 2002. Available online: https:/ / curia.europa.eu/juris/liste.jsf?language=en\&num=C-396/00 (accessed on 14 August 2021).

23. Thames Water. Our Supply Area. 2019. Available online: https://corporate.thameswater.co.uk/about-us/our-business/oursupply-area (accessed on 28 January 2021).

24. Allen, J.; Pryke, M. Financialising Household Water: Thames Water, MEIF, and Ring-Fenced Politics. Camb. J. Reg. Econ. Soc. 2013, 6, 419-439. [CrossRef]

25. Central Bank of the Russian Federation. On Revocation of Banking Licence and Appointment of Provisional Administration. 2016. Available online: http:/ / www.cbr.ru/eng/press/PR/?file=05022016_104902eng2016-02-05T10_45_45.htm (accessed on 8 May 2021).

26. ATO. Piano d'Ambito-Aggiornamento 2014-2037. Città di Milano. 2015. Available online: http:/ / www.atocittametropolitanadimilano. it/documenti/ambito/CdM/Allegato_2_Deliberazione_6_2015_PianoAmbito.pdf (accessed on 21 March 2021).

27. Cetti, S. MM SpA: Integrated Water Service Investments and Financing Strategy for the City of Milan. In The Italian Water Industry; Gilardoni, A., Ed.; Springer: Berlin, Germany, 2018.

28. Gruppo CAP. WebGis Acque di Lombardia. 2019. Available online: https://www.gruppocap.it/attivita/webgis/il-progetto (accessed on 22 March 2021). 
29. Renn, O.; Klinke, A.; Schweizer, P.-J. Risk Governance: Application to Urban Challenges. Int. J. Disaster Risk Sci. 2018,9 , $434-444$. [CrossRef]

30. Renn, O.; Lucas, K.; Haas, A.; Jaeger, C. Things are different today: The challenge of global systemic risks. J. Risk Res. 2017, 22, 401-415. [CrossRef] 